\title{
Information literacy training for teachers in a developing South African context: suggestions for a multi-disciplinary planning approach
}

\section{Ina Fourie and Kirstin Krauss}

Ina Fourie

Department of Information Science

University of Pretoria

ina.fourie@up.ac.za

Kirstin Krauss

Department of Informatics

University of Pretoria

kirstin.krauss@up.ac.za

\section{Abstract}

Information literacy and skills in Internet searching are important for teachers. There exists a large body of literature on information literacy in schools and universities and there are many guidelines and standards on information literacy. Little has, however, been published on information literacy training for teachers per se. Even less has been written on information literacy training for townships and rural communities in developing contexts where teachers may face special challenges. This article will argue that information literacy training for teachers in such communities can benefit from tailored planning influenced by Information Communication Technology (ICT) for Development (ICT4D) literature and taking into account factors such as relationship-building with a committed community; adaptation of the definition and standards for information literacy; and selecting appropriate methods and theories to support ongoing research. These suggestions came out of an United Nations Economic, Social and Cultural Organization (UNESCO) funded initiative by the Departments of Informatics and Information Science (University of Pretoria) to train teachers in information literacy in a township area close to Pretoria, South Africa. 


\section{Introduction}

The value of information literacy and Internet searching is widely recognised in many contexts ranging from schools to academic institutions and the workplace (Aharony 2010; Cheuk 1998). In recent years the inclusion of Internet searching in particular, as forming part of information literacy, is a given (Açikalin 2009; Sorensen et al 2007). According to Aharony (2010: 261), "Information literacy is a necessary skill that is useful in every aspect of life, especially in the twentyfirst century where we are inundated with vast amounts of information".

There is a good body of literature on school libraries and teachers, teachers' Internet usage and the broader context of school libraries promoting information literacy in addition to information literacy in a wide spectrum of contexts (Aharony 2010). Literature dealing with information literacy training for teachers per se is, however, rather limited; some of the exceptions being Emmons et al (2009), Engel (2010), Duke and Ward (2009), Floyd, Colvin and Bodur (2008), Merchant and Hepworth (2002), Probert (2009), Usluel (2007), Wen and Shih (2008), Williams and Coles (2007), Williams and Wavell (2007) and Krauss and Fourie (2010).

From work undertaken in South Africa, reported by Krauss and Fourie (2010) it seems as if Information Communication Technology for Development (ICT for Development or ICT4D) may offer a research focus that can help to deepen understanding of how to teach ICT and information literacy skills to teachers. The essence of this field is captured well in the views of Avgerou (2009) who argues that many studies explore the ways in which Information Technology (IT) and IT implementation can bring about improvements in people's lives by considering how it is being used, how people innovate with it, how it is applied in various communities and countries and how it affects growth and development. Researchers in the field also argue that human development can be enabled through access and use of ICTs, and by enabling personal freedoms to be achieved, for example, the freedom to research their personal goals (Qureshi 2010). Although the exact origins of the concept ICT4D is not clear, in their 1998 / 1999 World Development Report called 'Knowledge for development', the World Bank provided an extensive review of how ICT can and is being used in developing countries to improve the lives of people in many different spheres (World Bank 1998). In essence it means that research is approached from a different point of view which may help to ensure that people such as teachers fully benefit from ICT and information literacy training. 
The value of information literacy and especially Internet search skills for teachers is well acknowledged. It increases access to a vast array of information resources, especially those freely available through Internet search facilities, enables teachers to tailor information according to their own circumstances (for example, for lesson plans and assessment) and improves the quality of learning material. Information literacy can also support teachers in coping with everyday life problems such as HIV-AIDS, children exposed to domestic violence and issues of environmental protection. According to Usluel (2007: 93)

Information literacy skills are among the key skills required for success in information-based societies. Consequently, teachers who undertake the responsibility of teaching and leading others should possess these skills. Developing a high level of efficacy in these skills will also affect the success of teacher work performance and personal success in an increasingly information-based society.

In addition, in the wider contexts of ICT, the literature shows that ICT also has the potential to contribute to socio-economic development and quality of life, informing about issues such as social exclusion, the digital divide, poverty and lack of access to resources for basic human needs (Avgerou and Walsham 2000; Krishna and Madon 2003). These issues are no less real for the South African teacher. However, many teachers in South Africa face poor or no access to computers, the Internet, printers and the software required. "[T]he unequal power evident in the discourse between industrialized and developing parts of the world is one of the most critical issues of contemporary society" (Avgerou, 2005).

There are many challenges to be faced in training in a developing country such as South Africa, especially in townships and rural areas. These challenges include the issues of sustainability, contextualisation, life-long learning, empowerment, personal well-being and maintaining dreams and hope (Krauss 2009a and b; Chigona and Chigona 2010). Although much can be learned from the vast array of textbooks on information literacy (Cox 2008; Torras and Saetre 2009), research articles (Duke and Ward 2009; Probert 2009; Usluel 2007; Williams and Coles 2007) and information literacy standards (for example, American Library Association (ALA) and Big6 (Eisenberg, Lowe and Spitzer 2004)), there are hardly any guidelines on (1) information literacy training of teachers as working adults, and (2) the special challenges faced by developing communities. Although there are reports on the training of teachers in ICT in rural areas and developing communities (Krauss 2009a and b; Krishna and Madon 2003), these do not address training in information literacy. Similarly 
the publications on information literacy in South Africa (some acknowledging the challenges that it faces as a developing country), do not refer to input from ICT for Development literature. As explained earlier ICT for Development is a field with experience in dealing with the complexities of ICT in developing and disadvantaged communities (Qureshi 2010; Avgerou 2009; Krauss 2009a and b).

Noting that most information literacy literature does not acknowledge the challenges in developing contexts from an ICT for Development perspective, and that ICT for Development literature has not yet extended to information literacy training per se, this article intends to raise awareness of this gap and to share suggestions for the planning of information literacy training of teachers in South Africa, specifically in townships or rural areas. This (along with further extensive research) might put us in a better position to deal with the challenges. Within the limited scope of the article, the intention is to use the suggestions in further work and to gain interest from school and academic libraries, and hopefully also the national and provincial departments of education. The ideal would be to have an information literate teacher work corps au fait in using the Internet in all geographic areas of South Africa.

\section{Re-interpreting the definition of information literacy in the context of a developing country}

Various types of literacy are mentioned in the subject literature. These include ICT literacy, media literacy, information literacy, and media and information literacy. The ALA definition of information literacy is widely adopted (Behrens 1994; Johnston and Webber 2003; UNESCO 2008). In the context of information literacy training in a developing country we decided to adapt a definition of Donner and Gorman (2006: 284) which is specifically aimed at developing countries; our additions to the definition are indicated in the last two bullets appearing outside the quotation marks.

Information literacy is seen as the "ability of individuals or groups:

- to be aware of why, how and by whom information is created, communicated and controlled, and how it contributes to the construction of knowledge,

- to understand when information can be used to improve their daily living or to contribute to the resolution of needs related to specific situations, such as work or school,

- to know how to locate information and to critique its relevance and appropriateness to their context, 
- to understand how to integrate relevant and appropriate information with what they already know to construct knowledge that increases their capacity to improve their daily living or to resolve needs related to specific situations that have arisen."

- $\quad$ to resolve personal, job-related or broader social issues and problems, as part of a life-long learning strategy (following the Council of Australian University Librarians' definition which aligns information literacy training with everyday life issues), and

- to enhance the ability of teachers to both achieve on a personal level (or to achieve personal well-being) as well as to pursue dreams such as to help others to achieve.

The last bullet is based on Sen's capability approach discussed in Zheng (2009) and Chigona and Chigona (2010) (this was added to bring the definition in line with the care-giving nature of teaching).

\section{Brief review of the literature addressing information literacy in South Africa}

Considering the limited scope of this article, the following review will be very brief - the intention is merely to substantiate the need to align the literature from ICT for Development with information literacy. Apart from a few publications on information literacy in the context of developing countries such as those of Donner and Gorman (2006) on information literacy education in Asian developing countries, Ashcroft and Watts (2005) on information professionals, and Ogunsola (2009) on health information literacy in developing countries, there are limited reports on information literacy in South Africa that can guide information literacy training of teachers in township and rural areas in South Africa.

The following publications appearing since 2004 are noted: Chipeta, Jacobs and Mostert (2009) report on teaching and learning of information literacy in selected institutions of higher learning in KwaZulu-Natal and Malawi, while De Jager and Nassimbeni (2003) explore the status of information literacy tuition in South African tertiary institutions, with Moll (2009) discussing information literacy in the curriculum. Selematsela (2009) reports on a collaborative case study in the production of quality information learning materials, following an earlier article by Selematsela and Du Toit (2007) on a competency profile for librarians involved in information literacy training. Van der Walt, Cloete and Jacobs (2007) discuss the design of an information literacy instruction 
programme for upper elementary children in the public library, with Hart (2006) reporting on public libraries and information literacy education in the Mpumalanga province. Somi and De Jager (2005) explore the role of academic libraries in the enhancement of information literacy (Fort Hare Library as a case study), with Boekhorst and Britz (2004) reporting on information literacy at school level and Chipeta (2010) offering a literature review on information literacy teaching and learning. September (1993) and Sayed (1998) are some of the few publications that explicitly dwell on the challenges South Africa is facing in information literacy and information literacy training. Although these publications may note the special challenges faced by South Africa as a developing country, they do not relate to ICT for Development as a field that may help in addressing challenges and ensuring success. In developing contexts it has been noted that failures of ICT for Development often outnumber successes (Avgerou and Walsham 2000).

A more extensive literature review building on information literacy and Internet training for teachers, ICT training for teachers and reports from ICT for Development is reflected in a conference paper by Krauss and Fourie (2010).

Against this background and following earlier initiatives on ICT training for teachers in rural South African areas (Krauss 2009a and b), a UNESCO-funded initiative for training teachers in information literacy with a focus on Internet searching was launched in a township area outside Pretoria.

\section{UNESCO-funded initiative}

Noting the need for, and the value of information literacy training for teachers, the Departments of Informatics and Information Science (University of Pretoria) embarked on a training project in May 2010 for a group of teachers from a township school approximately 70 kilometres from Pretoria. Noting numerous calls for information literacy training to build on training in ICT (Idiodi 2005; Usluel 2007), the training included two components (also referred to as modules):

- Basic Applied Computer Literacy, addressing ICT skills as a requirement for information literacy, and

- Information Literacy for Teachers (focusing on Internet search skills within the wider context of available information sources. This means that although the teachers were trained in Internet searching, frequent reference was made to other important resources of information). The decision to focus on the Internet followed from the limited time the 
teachers as working adults had available and the perceived value of the Internet as an information resource. Other means for obtaining information such as books, talking to colleagues and experts were, however, highlighted throughout.

Although the training built on UNESCO's draft Media and Information Literacy (MIL) curriculum which was discussed in November 2009 with various stakeholders in Southern Africa and other international standards and frameworks such as the Big6 and the ALA standards, the time constraints of the teachers as working adults meant that the training had to be adapted. It focused only on Internet searching as part of the wider spectrum of information resources. In essence the training focused on recognising an information need, translating an information need into search terms and search strategies, effective use of search tools such as Google, as well as raising awareness of a selection of other useful search tools for example, searching for images and videos. Exercises, examples, and assessment were contextualised in the daily tasks of teachers as well as the context they face. (More detail on the scope of the training is reported in a paper by Krauss and Fourie at the 4th International Development Informatics Association (IDIA) conference held in Cape Town, November 2010.)

What seemed important for the purposes of this article is to share the planning approach and the potential value of ICT for Development.

\section{Planning guidelines for information literacy training for teachers in a developing context}

Although making a small difference, a once-off project is not sufficient to address the dire need in South Africa for information literacy training for teachers. Ongoing efforts and research are required to deepen our understanding of such training. From the experiences gained in the UNESCO funded training and ICT training for teachers in other rural South African areas (Krauss 2009a and b), guidelines are suggested that can contribute to an ongoing researchbased initiative and developing a body of knowledge not only on the practicalities of training in information literacy in townships and rural areas, but also addressing challenges such as sustainability, contextualisation, life-long learning, and empowerment in the larger context. (During the UNESCO-funded training feedback on such issues was collected from trainees. This will be reported in a separate publication.) 
The following guidelines or principles (influenced by insights from ICT for Development) are suggested to support planning:

(1) Identifying an interested and committed community of teachers. Apart from identifying a community that is interested in setting time aside (in the case of the UNESCO funded project teachers had to attend for nine Saturdays from 8:00 - 13:00), good rapport, and a trust relationship should be established. This is also referred to as establishing an entry into the community - an aspect on which Krauss (2009a, b) elaborates.

(2) Scrutinising existing standards and frameworks on information literacy that can be adapted according to the needs of the local contexts for example, the Big6, ALA guidelines in various contexts, Standing Conference of National and University Libraries (SCONUL) Seven Pillars of Information Literacy, Association of College and Research Libraries (ACRL) Standards, the IFLA guidelines on Information Literacy and life-long learning, SYLIS guidelines for the South Africa context and the UNESCO draft Media and Information Literacy (MIL) curriculum. Apart from the needs of the South African and especially rural community, the task-related needs of teachers and particularly their position as working adults also need to be considered (Knowles, Holton and Swanson 2005).

(3) Extensive multi-disciplinary literature reviews ${ }^{1}$. Krauss and Fourie (2010) reviewed the library and information science literature on information literacy and Internet usage for teachers (for example, Crouse and Kasbohm 2004; Duke and Ward 2009; Emmons et al 2009), as well as reports on information literacy training in developing contexts and rural areas (for example, Donner and Gorman 2006). They also explored reports on training in ICT (for example, Ashcroft and Watts 2005; Krauss 2009a and b) and reports on the use of the Internet in teaching (for example, Sorensen et al. 2007; Teale et al. 2002; Açikalin 2009). In the extensive literature review (not reflected here) no evidence could be found of acknowledging input from ICT for Development and Information Systems theories - two fields that address, among other things, the successful adoption of ICT and related skills in developing communities (Chigona and Chigona 2010; Krishna and Madon 2003; Zheng 2009). Future literature reviews might also cover Information Behaviour and Adult Learning (Andragogy).

(4) Preliminary analysis of the teachers as educators and mediators in their communities including their job-related tasks, extramural responsibilities, and community involvement. It is assumed that much can be learned from research on task-related information behaviour (i.e. information seeking related to job, academic or daily tasks) (Vakkari 2003). The link between research on information literacy and information behaviour and task-related information seeking (i.e. how information seeking, search moves, search 
strategies, etc. are influenced by the tasks a person is expected to complete or by a specific search task assigned to them), however, still needs to be further explored and spelled out.

(5) Challenges and barriers that have been reported in the subject literature on ICT training in rural communities (Krauss 2009b), as well as the wider context of information literacy training and information literacy training for teachers (Cox 2008; Grassian and Kaplowitz 2009; Johnston and Webber 2003; Torras and Saetre 2009) need to be acknowledged. Williams and Coles (2007:186) found that, although teachers were mostly positive towards what they referred to as "finding and using research evidence" they, the teachers, felt that time and access to sources were a problem. According to them this lack of access to resources and time were likely to be limiting factors "in terms of the development of teacher confidence in finding, evaluating and using the kinds of information sources which are increasingly available...." The impact of anxiety about ICT and information literacy on high school teachers has also been noted (Chou 2003).

(6) Contextualising content according to perceived information needs and interests. In theories of adult learning (Knowles, Holton and Swanson 2005) as well as experiences in ICT training in rural areas, contextualisation according to the needs of trainees is stressed (Krauss 2009b; Duke and Ward 2009). The latter stresses the importance of authentic learning assignments that require real-world information resources (i.e. relating to what is available in their daily contexts). In terms of contextualisation, Krishna and Madon (2003) also stress the importance of a group taking ownership of training, while Lewis (1994) and Krishna and Madon (2003) stress the challenge to help the local community see hope and to become motivated to contribute to their own development and adequately assess their own talents, abilities and resources. Although only on a preliminary basis, these challenges were addressed in the UNESCO funded training initiative. More will be learned from the data collected during the training, to be incorporated into future initiatives.

(7) Aligning training programmes with the needs, experiences, expectations and realities (for example, a teacher strike starting in the last week of the training) and socio-cultural conditions faced by teachers in townships and rural contexts in South Africa (Mokgalabone 1999; Chikoko 2008). Lewis (1994) and Krauss (2009a) also stress the need to deal with Afrocentricity as well as the power relations in intercultural communication. Addressing these issues in the information literacy training of teachers may offer interesting results - to be considered in future training.

(8) Selecting an appropriate research paradigm and methodological approach to support the training and to study the impact and experiences of the 
trainees. In this regard ICT for Development literature and Critical Social Theory (CST) seem to hold potential (Krauss 2009b). CST is one of the research paradigms in the field of Information Systems and ICT for Development. It takes a critical stance on the social phenomena being studied. CST implies that researchers cannot only be observers of the social phenomena. They are influenced by the social and technological systems they are studying and they also influence what they study (Krauss 2009b). The emphasis is on the social context and life-world of the people involved and emancipation (Ngwenyama and Lee 1997). More so, the intention is to go beyond the surface of what is being observed and to focus on unequal and unjust conditions and to help people to change conditions and to build a better world for themselves (Neuman 1997). Mutual understanding, intercultural communication, and addressing false and unwarranted beliefs, assumptions and constraints are important (Krauss 2009b). The intention of CST is to question whether ICT initiatives are really important, right, good and ethical for community development.

\section{Conclusion}

There is a dire need for information literacy training of teachers in South Africa, particularly in rural areas - as students in training, but also as working adults, and this could be addressed by considering the approach of ICT for Development as well as international standards and curricula for information literacy, such as the UNESCO MIL and Big6. Such an approach would also need to follow a plan based on the in situ challenges of teachers, a widening systematic review of supporting literature, and applying a critical position of inquiry. The small body of existing research and literature suggests making Internet searching a focus of information literacy because of the wide variety of information freely available to meet both professional and personal needs, despite the challenges of access to computer hardware and software. This article has provided an outline of a specific initiative to provide a community of teachers with information literacy skills based on an ICT for Development approach with a focus on the planning of such an event. This initiative has allowed researchers to learn from the local community, and align the findings of research from ICT for Development with that from the literature of information literacy so as to develop a platform for the ongoing development of training and research on information literacy for teachers in particular. 


\section{References}

Açikalin, M. 2009. Pre-service elementary teachers' beliefs about use of the Internet in the social studies classroom. European journal of teacher education 32(3): 305-320.

Aharony, N. 2010. Information literacy in the professional literature: an exploratory analysis. Aslib proceedings: new information perspectives 62(3): 260-282.

American Library Association. http://www.ala.org/ala/mgrps/divs/aasl/aaslproftools/informationpower/informat ionpower.cfm Accessed 18 November 2010.

Ashcroft, L. and Watts, C. 2005. ICT skills for information professionals in developing countries: perspectives from a study of the electronic information environment in Nigeria. IFLA journal 31(6): 6-12.

Avgerou, C. 2005. Doing critical research in information systems: some further thoughts. Information systems journal 15: 103-109.

Avgerou, C. 2009. Discourses on innovation and development in information systems in developing countries' research. Proceedings of the 2009 IFIP WG 9.4 Conference.

Avgerou, C. and Walsham, G. (eds.) 2000. Information technology in context: studies from the perspective of developing countries. Burlington: Ashgate.

Behrens, S.J. 1994. A conceptual analysis and historical review of information literacy. College and research libraries 55(4): 309-322.

Big6. Available at: http://www.big6.com/ Accessed 18 November 2010.

Boekhorst, A. and Britz, J.J. 2004. Information literacy at school level: a comparative study between the Netherlands and South Africa. South African journal of libraries and information science 70(2): 63-71.

Cheuk, B. 1998. An information seeking and using process model in the workplace: a constructivist approach. Asian libraries 7(12): 375-390. 
Chigona, A. and Chigona, W. 2010. An investigation of factors affecting the use of ICT for teaching in the Western Cape schools. Proceedings of the 18th European Conference on Information Systems, Pretoria, South Africa, June 7-9.

Chikoko, V. 2008. Developing teachers for rural education? Reflecting on the 2nd KwaZulu-Natal Department of Education teacher development conference: research article. Perspectives in education 26(4): 74-85.

Chipeta, G.T. 2010. Information literacy (IL) teaching and learning: a literature review. Inkanyiso: Journal of humanities and social science 2(1): 21-31.

Chipeta, G., Jacobs, D. and Mostert, J. 2009. Teaching and learning of information literacy in some selected institutions of higher learning in KwaZulu-Natal and Malawi. South African journal of libraries and information science 75(1): 46-57.

Chou, C. 2003. Incidences and correlates of Internet anxiety among high school teachers in Taiwan. Computers in human behavior 19: 731-749.

Cox, C.N. (ed.) 2008. Information literacy instruction handbook. Chicago: Association of College and Research Libraries.

Crouse, W.F. and Kasbohm, K.E. 2004. Information literacy in teacher education: a collaborative model. The educational forum 69(1): 44-52.

De Jager, K. and Nassimbeni, M. 2003. An exploration of the current status of information literacy tuition in South African tertiary institutions and proposals for curriculum design. South African journal of libraries and information science 69(2): 108-114.

Donner, G.D. and Gorman, G.E. 2006. Information literacy education in Asian developing countries: cultural factors affecting curriculum development and programme delivery. IFLA journal. 32: 281-293.

Duke, T.S. and Ward, J.D. 2009. Preparing information literate teachers: a metasynthesis. Library and information science research 31(4): 247-256.

Emmons, M., Keefe, E.B., Moore, V.M., Sánchez, R.M., Mals, M.M. and Neely, T.Y. 2009. Teaching information literacy skills to prepare teachers who can bridge the research-to-practice gap. Reference and user services quarterly, 49(2): 140-150. 
Engel, D. 2010. Guiding students into information literacy: strategies for teachers and teacher-librarians. Reference and user services quarterly 49(4): 400-401.

Eisenberg, M.B., Lowe, C.A. and Spitzer, K.L. 2004. Information literacy: essential skills for the information age. 2nd ed. Westport, Conn.: Libraries Unlimited.

Floyd, D.M., Colvin, G. and Bodur, Y. 2008. A faculty-librarian collaboration for developing information literacy skills among preservice teachers. Teaching and teacher education 24(2): 368-376.

Grassian, E.S. and Kaplowitz, J.R. 2009. Information literacy instruction: theory and practice. 2nd ed. New York: Neal-Schuman Publishers.

Hart, G. 2006. Public librarians and information literacy education: views from Mpumalanga Province. South African journal of libraries and information science 72(3): 172-184.

Idiodi, E.A. 2005. Approaches to information literacy acquisition in Nigeria. Library review 54(4): 223-230.

Johnston, B. and Webber, S. 2003. Information literacy in higher education: a review and case study. Studies in higher education 28(3): 335-352.

Knowles, M.S., Holton, E.F., and Swanson, R.A. 2005. The adult learner: the definitive classic in adult education in human resource development. 6th ed. Amsterdam: Elsevier.

Krauss, K. 2009a. Ethical research practice for community entry: using ICT4D in a deep rural context. Proceedings of the 3rd International IDIA Development Informatics Conference, Kruger National Park, South Africa, October 28-29.

Krauss, K. 2009b. The collision between international ICT policy and a deep rural community in South Africa: interpretation, implementation and reality. Proceedings from the 2nd Annual SIG GlobDev Workshop, 14 December 2009, Phoenix, Arizona.

Krauss, K. and Fourie, I. 2010. Towards information literacy training for teachers in rural South African communities: research in progress. IDIA Conference, November, Cape Town. 
Krishna, S. and Madon, S. (eds.) 2003. The digital challenge: information technology in the development context. Burlington: Ashgate.

Lewis, J. Ed . 1994. World Mission: an analysis of the world Christian movement. 2nd ed. Pasadena; William Carey Library.

Merchant, L. and Hepworth, M. 2002. Information literacy of teachers and pupils in secondary schools. journal of librarianship and information science 34(2): 81-89.

Mokgalabone, M.B. 1999. Socio-cultural conditions, teenage pregnancy and schooling disruption: themes from teachers and teenage mothers in poor rural schools. South African journal of education 19(1): 55-66.

Moll, M. 2009. Information literacy in the new curriculum. South African journal of libraries and information science 75(1): 40-45.

Neuman, W.L. 1997. Social research methods: qualitative and quantitative methods. 3rd ed. Boston, Mass.: Allyn and Bacon.

Ngwenyama, O.K. and Lee, A.S. 1997. Communication richness in electronic mail: critical social theory and the contextuality of meaning. MIS quarterly journal 21(2): 145-167.

Ogunsola, L.A. 2009. Health information literacy: a road map for poverty alleviation in the developing countries. Journal of hospital librarianship 9(1): 59-72.

Probert, E. 2009. Information literacy skills: teacher understanding and practice. Computers and education 53: 24-33.

Qureshi, S. 2010. Editoral: Extending human capabilities through information technology application and infrastructures. Information technology for development 16(1): 1-3.

Sayed, Y. 1998. The segregated information highway: information literacy in higher education. Cape Town: University of Cape Town Press.

Selematsela, D. 2009. Collaborative case study in the production of quality information learning materials. Progressio 31(1 and ): 38-45. 
Selematsela, D. and Du Toit, A. 2007. Competency profile for librarians teaching information literacy. South African journal of libraries and information science 73(2): 119-129.

September, P.E. 1993. Promoting information literacy in developing countries: the case of South Africa. South African journal of library and information science 3(1): 11-22.

Somi, N.G. and De Jager, K. 2005. The role of academic libraries in the enhancement of information literacy: a study of the Fort Hare Library. South African journal of libraries and information science 71(3): 259-267.

Sorensen, P., Twilde, J., Childs, A. and Godwin, J. 2007. The use of the Internet in science teaching: a longitudinal study of developments in use by studentteachers in England. International journal of science education 29(13): 16051627.

Teale, W.H., Leu, D.J.(Jr.), Labbo, L.D. and Kinzer. C. 2002. Exploring literacy on the Internet; the CTELL project: new ways of technology can help educate tomorrow's reading teachers. The reading teacher 55(7): 654-659.

Torras, M-C. and Saetre, T.P. 2009. Information literacy education: a process approach: professionalising the pedagogical role of academic libraries. Oxford: Chandos.

UNESCO. 2008. ICT-CST policy framework.

http://portal.unesco.org/ci/en/ev.phpURL_ID $=25740 \& U R L$ DO $=$ DO_TOPIC\& URL_SECTION $=201 . \mathrm{html}$ Accessed 18 November 2010.

Usluel, Y.K. 2007. Can ICT usage make a difference on student teachers' information literacy self-efficacy? Library and information science research 29: 92-102.

Vakkari, P. 2003. Task-based information searching. Annual review of information science and technology 37: 413-464.

Van der Walt, P.R., Cloete, L.M. and Jacobs, L. 2007. The design of an information literacy instruction programme for upper elementary children in the public library. Mousaion 25(1): 82-98. 
Wen, J.R. and Shih, W.L. 2008. Exploring the information literacy competence standards for elementary and high school teachers. Computers and education 50(3): 787-806.

Williams, D. and Coles, L. 2007. Teachers' approaches to finding and using research evidence: an information literacy perspective. Educational research 49(2): 185-206.

Williams, D.A. and Wavell, C. 2007. Secondary school teachers' conceptions of student information literacy. Journal of librarianship and information science 39(4): 199-212.

World Bank. 1998. World development report: knowledge for development. New York: OUP.

Zheng, Y. 2009. Different spaces for e-development: what can we learn from the Capability Approach? Information technology for development 15(2): 66-82.

\section{Endnote}

${ }^{1}$ Only a few key references are mentioned here due to constraints on length; more detail can be found in Krauss and Fourie (2010). 